\title{
Retinoic Acid as a Modulator of T Cell Immunity
}

\author{
Maria Rosa Bono ${ }^{1}$, Gabriela Tejon ${ }^{1}$, Felipe Flores-Santibañez ${ }^{1}$, Dominique Fernandez ${ }^{1}$, \\ Mario Rosemblatt ${ }^{1,2,3}$ and Daniela Sauma ${ }^{1, *}$ \\ 1 Departamento de Biologia, Facultad de Ciencias, Universidad de Chile, Las Palmeras 3425, Nuñoa, \\ Santiago 7800003, Chile; mrbono@uchile.cl (M.R.B.); Gabrielatejon@gmail.com (G.T.); \\ felipeflores.uchile@gmail.com (F.F.-S.); dominique.fernandez.q@gmail.com (D.F.); \\ mrosemblatt@cienciavida.org (M.R.) \\ 2 Fundacion Ciencia \& Vida, Santiago 7780272, Chile \\ 3 Facultad de Ciencias Biologicas, Universidad Andres Bello, Santiago 8370146, Chile \\ * Correspondence: dsauma@u.uchile.cl; Tel.: +56-2-2978-7339
}

Received: 23 April 2016; Accepted: 1 June 2016; Published: 13 June 2016

\begin{abstract}
Vitamin A, a generic designation for an array of organic molecules that includes retinal, retinol and retinoic acid, is an essential nutrient needed in a wide array of aspects including the proper functioning of the visual system, maintenance of cell function and differentiation, epithelial surface integrity, erythrocyte production, reproduction, and normal immune function. Vitamin A deficiency is one of the most common micronutrient deficiencies worldwide and is associated with defects in adaptive immunity. Reports from epidemiological studies, clinical trials and experimental studies have clearly demonstrated that vitamin A plays a central role in immunity and that its deficiency is the cause of broad immune alterations including decreased humoral and cellular responses, inadequate immune regulation, weak response to vaccines and poor lymphoid organ development. In this review, we will examine the role of vitamin A in immunity and focus on several aspects of $\mathrm{T}$ cell biology such as Thelper cell differentiation, function and homing, as well as lymphoid organ development. Further, we will provide an overview of the effects of vitamin A deficiency in the adaptive immune responses and how retinoic acid, through its effect on $\mathrm{T}$ cells can fine-tune the balance between tolerance and immunity.
\end{abstract}

Keywords: retinoic acid; vitamin A; T cell; oral tolerance; homing

\section{Introduction}

In the early 20th century, several researchers performed studies on laboratory animals to identify essential dietary components. Hopkins, McCullum, Osborne, and Mendel reported that animals fed with only fats, proteins, starch and inorganic salts, were more susceptible to infections and failed to grow normally. Administration of the factors present in dairy products and cod liver oil prevented these complications. McCollum called this factor "fat-soluble accessory" [1]. In 1928, Green and Mellanby reported that vitamin A, played an important role in conferring resistance to many infections and declared vitamin A as an anti-infective agent [2]. The role of vitamin A in immunological fitness was confirmed in randomized clinical trials performed in the 1980-1990s studying the effect of vitamin A supplementation on child mortality in Africa and Asia. These trials resulted in a significant reduction of mortality among children of 1-5 years of age where most of the deaths prevented were associated with less severe clinical manifestations of measles and diarrheal disease [1,3]. Furthermore, although several studies have reported that vitamin A increases antibody production which has led to the supplementation of vaccines with vitamin $A$, results from human immunization programs have not shown a significant effect on vaccine efficacy upon vitamin A supplementation [4]. Despite all these efforts, today vitamin A deficiency (VAD) is still one of the most common micronutrient deficiencies, affecting approximately one-third of the world's preschool-age population [5] and remains the primary 
cause of immunosuppression worldwide [6]. In recent years, and with the development of better models and experimental techniques, it has become clear that vitamin A, through its metabolite retinoic acid (RA), has a broad impact on diverse aspects of the immune response, including mucosal immunity, tolerance, leukocyte trafficking and lymph node organogenesis.

\section{Vitamin A Metabolism and Retinoic Acid Signaling}

Dietary vitamin A is obtained through the consumption of foods containing vitamin A precursors, such as carotenoids, or vitamin A in the form of retinyl esters. The proximal portion of the gut is the primary tissue where vitamin A precursors, like $\beta$-carotene, are converted to retinoids in the lumen by enterocytes. Dietary precursors are incorporated into nascent chylomicrons and enter the general circulation. Following their absorption and arrival in the circulation, retinyl esters are stored in the liver, where they are hydrolyzed into retinol and delivered into the circulation $[7,8]$.

The three active forms of vitamin A (retinal, retinol and retinoic acid) serve different physiological functions. For instance, 11-cis retinal plays an important role in vision as it functions as a light-sensitive chromophore that binds and maintains the stability of rhodopsin [9]. On the other hand, retinol circulates in plasma, bound to the Retinol Binding Protein (RBP), and in this form serves as a source of RA [10]. RA, the main vitamin A metabolite, has been involved in the control of gene expression in a variety of processes including immune function.

$\mathrm{RA}$ is generated from retinol after two sequential reactions. The first reaction involves the reversible conversion of retinol to retinaldehyde, also known as retinal. Initially, it was reported that this reaction was catalyzed by a subfamily of alcohol dehydrogenases (ADHs) that include ADH1, ADH5 and ADH7 [11,12]. However, more recent evidence has demonstrated that these ADHs do not contribute to RA synthesis under normal physiological conditions and that only short-chain dehydrogenases/reductases such as microsomal retinol dehydrogenases (RDHs) are the physiologically relevant enzymes in the conversion of retinol to retinaldehyde [13]. In a second reaction, retinal is irreversibly converted to RA by one of the three retinal dehydrogenase isoforms RALDH1, RALD2 and RALDH3, which form a subfamily of class I aldehyde dehydrogenases [12]. Since RALDH expression is tightly regulated, this enzyme is considered the key enzyme defining particular cell populations that are able to produce RA [14].

Most of the immunological functions associated with vitamin A are mediated by RA in the form of all-trans-RA and 9-cis-RA. RA binds to nuclear receptors, including retinoic acid receptors (RAR), retinoid X receptors (RXR) and PPAR $\beta \delta$. The RAR family of receptors includes three receptors: RAR $\alpha$, RAR $\beta$ and RAR $\gamma$ [15]. RARs form heterodimers with RXR to regulate target gene expression through the binding to retinoic acid-responsive elements (RARE) [16]. Both all-trans-RA and 9-cis-RA are ligands of the nuclear receptors $\operatorname{RAR} \alpha, \operatorname{RAR} \beta$, and $\operatorname{RAR} \gamma$, whereas only 9-cis-RA can bind nuclear RXR $[17,18]$.

RAR/RXR heterodimers constitutively bind to RAREs. In the absence of ligands, RAR/RXR heterodimers recruit corepressors to inhibit the transcription of target genes, whereas the binding of RAR/RXR ligands displaces the corepressors, allowing the recruitment of coactivators and resulting in the transcriptional activation of target genes [19-21]. Most of the RA immune-related functions signal through the RAR/RXR pathway, which is driven by all-trans-RA acting through $\operatorname{RAR} \alpha$ [22].

\section{Retinoic Acid and T Cell Homing}

Following their activation in lymph nodes, in order to execute their function, antigen-experienced $\mathrm{T}$ cells must migrate into different tissues following a multistep cascade of events. The preferential trafficking to a specific tissue, known as T cell "homing", is tightly regulated by the expression of different adhesion molecules or distinct "molecular zip codes" on T cells [23]. These adhesion molecules allow $\mathrm{T}$ cells to bind to addressins present in the endothelium allowing for their arrest and entry to target sites [24]. 
Adhesion molecules involved in $\mathrm{T}$ cell homing to the intestine have been extensively studied. It has been demonstrated that the expression of the $\alpha 4 \beta 7$ integrin and CCR 9 chemokine receptor by $\mathrm{T}$ cells is crucial for $\mathrm{T}$ cell migration to the gut in absence of inflammation [23,25]. CCL25, the ligand of CCR9, is expressed by intestinal epithelial cells whereas Mucosal Addressin Cell Adhesion Molecule-1 (MAdCAM-1), the ligand of $\alpha 4 \beta 7$ is expressed by high endothelial venules in gut-associated lymphoid tissue [24].

The factors determining the induction of specific adhesion molecules on $\mathrm{T}$ cells were discovered few years ago. In 2003, our group reported that dendritic cells (DCs) are able to instruct T cells to migrate to different tissues. In this study, intestinal DCs from Peyer's patches and mesenteric lymph nodes but not from spleen or peripheral lymph nodes were able to induce the gut-homing receptors $\alpha 4 \beta 7$ and CCR9 on CD8 ${ }^{+}$T cells [26]. Shortly after that study, it was demonstrated that RA is the factor responsible in the induction of gut-homing receptors on $\mathrm{CD}^{+} \mathrm{T}^{\mathrm{T}}$ cells [27] (Figure 1), CD8 ${ }^{+} \mathrm{T}$ cells [28] and IgA-secreting B cells [29,30]. Interestingly, RA not only induces gut-homing receptors on T cells but also inhibits skin homing receptors, such as E-Selectin ligands [27]. Most importantly, CD4 ${ }^{+}$and $\mathrm{CD}^{+} \mathrm{T}$ cell homing to the small intestine lamina propria is impaired in VAD mice, confirming the essential role of RA in T cell homing to the gut [27]. The effect of RA on $\alpha 4 \beta 7$ and CCR9 expression is mediated by RAR $\alpha$ which binds to RAR-response elements within the regulatory region of the gene that encodes $\alpha 4$ [31,32], and forms RAR $\alpha / R X R$ heterodimers that bind to a RARE in the promoter region of CCR9 [33].

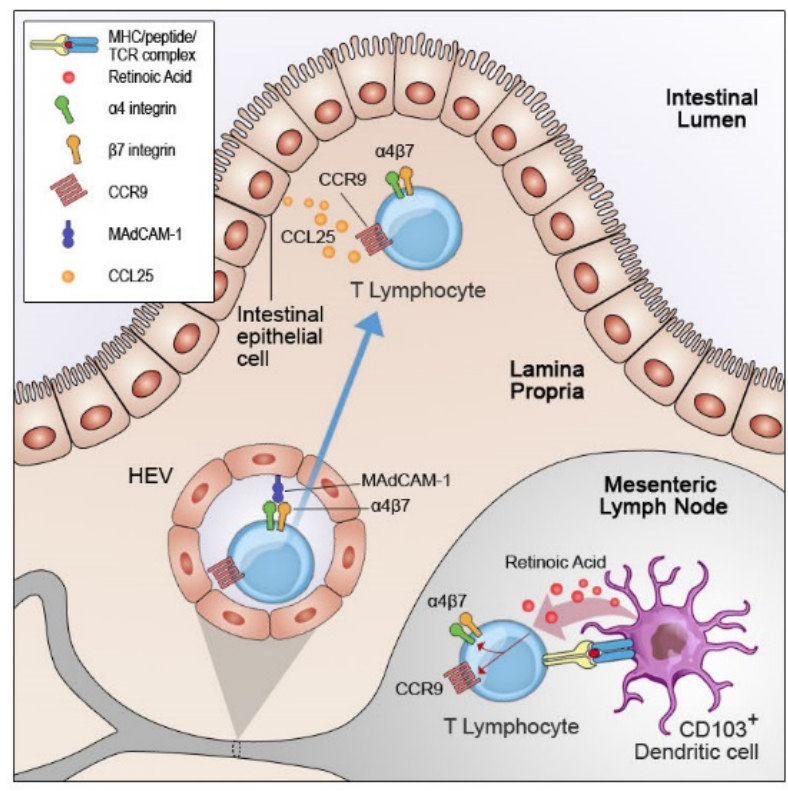

Figure 1. Retinoic acid induces $\mathrm{T}$ cell homing to the gut. A specialized subset of gut-resident dendritic cells which express CD103 integrin is able to produce retinoic acid during the interaction with T cells in the mesenteric lymph node. Retinoic acid induces the expression of $\alpha 4$ which binds to $\beta 7$ forming the $\alpha 4 \beta 7$ integrin. $\alpha 4 \beta 7$ integrin binds to the mucosal addressin cell adhesion molecule 1 (MadCAM-1) which is expressed by high endothelial venules (HEV) in the intestinal tissue. Retinoic acid also induces the expression of the chemokine receptor CCR9, which binds to CCL25 chemokine produced by intestinal epithelial cells. The expression of $\alpha 4 \beta 7$ and CCR 9 allows the trafficking of $T$ cells to the lamina propria.

After the discovery of RA as a master controller of T cell homing to the gut, special focus has been placed on determining the cellular source of RA. DCs from Peyer's patches and mesenteric lymph nodes express RALDH1 and RALDH2 mRNAs, respectively, which are the key enzymes for the conversion of vitamin A to RA. In contrast, DCs obtained from spleen express only marginal levels of 
RALDH1 mRNA and essentially no RALDH2 and RALDH3 mRNAs. Furthermore, DCs isolated from Peyer's patches and mesenteric lymph nodes, but not those isolated from spleen produce RA from retinol when co-cultured with T cells and their specific antigen [27]. Further studies have shown that a subset of DCs that are enriched in the small intestine and express the CD103 integrin, present high levels of RALDH2 mRNA and thus are specialized in the production of RA [34-36].

Others have reported that RA may be produced locally at sites of inflammation [37]. This finding raises the intriguing possibility that RA may also be involved in the migration of $\mathrm{T}$ cells to inflamed sites. RA is able to induce $\alpha 4$ integrin which, in addition to forming heterodimers with $\beta 7$, may also form heterodimers with integrin $\beta 1 . \alpha 4 \beta 1$, in turn, binds to Vascular Cell Adhesion Molecule-1 (VCAM-1), which is upregulated by the endothelium during inflammation [24]. Along these lines, using skin transplantation as a model of inflammation, Pino-Lagos and collaborators have shown that $\mathrm{T}$ cells deficient in RA signaling have altered migration to sites of inflammation, such as the skin graft [37].

\section{Role of Retinoic Acid in Regulatory T Cell Differentiation}

The intestine is colonized by a vast community of commensal microbes and is constantly exposed to dietary antigens. However, the intestinal immune system has strategically evolved to efficiently discriminate between these innocuous stimuli and pathogenic microorganisms. Oral tolerance is defined as a state of local and systemic immune unresponsiveness that is induced by the oral administration of an innocuous antigen. It is now recognized that regulatory $\mathrm{T}$ cells (Tregs) are crucial in maintaining immune homeostasis and tolerance to commensal microbiota and food proteins in the gut [38].

Regulatory $\mathrm{T}$ cells constitute a subset of $\mathrm{CD}^{+} \mathrm{T}$ cells responsible for inducing and maintaining peripheral tolerance [39]. Depending on their origin, Tregs can be classified into two subpopulations: thymus-derived Tregs, which are generated in the thymus and circulate in the periphery as functional mature Tregs [40], and peripherally derived Tregs, which are generated in the periphery from CD4 ${ }^{+}$ naive T cells in the presence of cytokines such as TGF- $\beta$ and IL-2 [41-43]. Both populations express the transcription factor Foxp3, the master regulator of Treg cell differentiation and effector functions [44].

Evidence of the role of extrathymic Treg differentiation in the induction of oral tolerance was presented by the Belkaid group in 2007, showing that the small intestine harbors the conditions for the de novo generation of Tregs. Transferred naive T cells can be converted to Tregs in the gut-associated lymphoid tissue where gut-associated DCs, through the production of RA, are responsible for this conversion [45]. This effect of RA on Treg differentiation was shown to be mediated through $\mathrm{RAR} \alpha[46,47]$. Since that seminal report, several groups have demonstrated that high concentrations of RA in combination with TGF- $\beta$ induce the expansion of murine $[35,45,48-50]$ and human Tregs in vitro [32,51-54].

Retinoic acid also induces Treg conversion indirectly, through the inhibition of cytokine production by a population of memory $\mathrm{T}$ cells that blocks the differentiation of naive $\mathrm{T}$ cells into Tregs [54-57]. This population of memory T cells (CD44 ${ }^{\text {hi }}$ ) produces IL-4, IL-21 and IFN- $\gamma$ and inhibits Treg cell differentiation in vitro. The addition of RA in culture limits cytokine production by these memory $\mathrm{T}$ cells and thus enhances Treg differentiation.

As pointed out above, RA synergizes with TGF- $\beta$ not only to induce the expansion of Tregs but it has been shown to sustain the stability and function of these cells during inflammation. We and others have shown that murine Tregs generated in the presence of RA present a more stable phenotype than Tregs differentiated without RA, even after these cells are challenged in vivo with their cognate antigen $[49,50]$ or in a setting of intestinal inflammation [58]. Zhou and collaborators have shown that Treg stability during collagen-induced arthritis is dependent on the reduction of IL-6 receptor $\alpha$ expression in Tregs generated in the presence of RA [59]. In addition, RA enhances TGF- $\beta$ signaling by increasing the expression and phosphorylation of $S \operatorname{mad} 3$, a transcription factor that regulates the expression of Foxp3. This results in increased Foxp3 expression, even in the presence of Th17-inducing 
cytokines, such as IL-6 or IL-21 [60,61]. RA in conjunction with TGF- $\beta$ are also important for the stability of human de novo generated Treg and thymus-derived Tregs, demonstrated by the maintenance of Foxp3 expression and suppressive function [52,54]. However, thymus-derived human Tregs maintained with RA alone lose their regulatory properties and differentiate into pro-inflammatory cells during an inflammatory response [51,53].

Several studies have shown that RA not only promotes the differentiation, stability and function of murine and human Tregs but also induce the expression of gut-homing receptors in these cells $[49,50,53,62]$. Despite this finding, Tregs generated in the presence of RA are capable of suppressing skin graft rejection [49], collagen induced arthritis [59] and allow the generation of mixed chimerism in transplant tolerance [63] suggesting that RA may also participate in the induction of other homing receptors.

In agreement with a role for RA in Treg induction, the administration of the pan-RAR antagonist LE540 in mice challenged with Listeria monocytogenes significantly reduces the number of mucosal Foxp3 $3^{+}$Tregs [64]. Similarly, in a model of experimental autoimmune uveitis, VAD mice exhibit a decreased frequency of intraocular Tregs [65]. Consistent with the effects produced by VAD, the administration of all-trans RA to normal mice leads to the expansion of Foxp3 ${ }^{+}$Tregs [66]. Moreover, de novo differentiation of Tregs from naive $\mathrm{T}$ cells is abrogated in VAD mice in a setting of oral tolerance [67], possibly due to a reduction in the trafficking of $T$ cells to the intestine. It has been demonstrated that RA is crucial for T cell trafficking to the gut [27], and this migration is required for the expansion of Tregs during the induction of oral tolerance [68].

Despite converging evidence pointing towards a role for RA in the differentiation of Tregs in vivo and in vitro, some groups have reported that the percentage or absolute number of endogenous Tregs in the intestine are not altered in VAD mice [67,69]. Moreover, mice carrying a dominant-negative form of the RA receptor RAR $\alpha$ in which RA signaling is impaired have a normal frequency and number of Tregs in the thymus and periphery [70]. Further studies are needed to fully understand the role of RA in the induction of extrathymic Tregs and its participation in oral tolerance.

\section{Retinoic Acid in T Helper Cell Differentiation and Activation}

Following activation, $\mathrm{CD} 4^{+} \mathrm{T}$ cells are able to differentiate into different $\mathrm{T}$ helper cell subsets that are classified according to their function, expression of lineage-specific master transcription factors, and secreted cytokines. Several T helper (Th) subsets have been described, which include Th1, Th2, Th17, $\mathrm{T}$ follicular helper (Tfh) and Tregs cells. $\mathrm{CD} 4^{+} \mathrm{T}$ cell differentiation into these different subsets is dependent on the cytokines present in the microenvironment during their activation [71].

Although overwhelming evidence supports the contribution of RA in tolerance via the negative regulation of the immune response through the induction or expansion of Tregs, recent evidence has shown that RA may also promote $\mathrm{T}$ cell activation and $\mathrm{T}$ helper cell responses during an ongoing immune response (Tables 1 and 2). In this section, we will discuss recent evidence demonstrating a role for RA in T helper differentiation and activation.

\subsection{Th17/Th1 Cell Differentiation}

A wealth of evidence indicates that at pharmacological or high doses (10 $\mathrm{nM}$ and higher), RA has been shown to inhibit Th17 cell responses while inducing the generation of Tregs in murine models in vitro $[46,61,64,72]$. Moreover, the addition of high doses of RA has been shown to impair the differentiation of human Th17 and Th1 cells in vitro [73], suggesting that at pharmacological doses, RA is able to inhibit Th1 and Th17 cell differentiation in human $\mathrm{CD}^{+} \mathrm{T}$ cells. Importantly, other studies suggest that RA may have a dose-dependent effect over Th17 cell differentiation and lower or physiological concentrations of RA fail to inhibit Th17 cell differentiation [74,75]. Thus, although initially RA was considered detrimental for Th1 and Th17 responses, all these data suggests that RA inhibits Th1 and Th17 cell differentiation only at pharmacological doses by tilting the balance towards the expansion or generation of Tregs. 
In contrast to the reports suggesting that RA inhibits Th1 and Th17 responses, some groups have reported that at low doses, RA favors Th1 and Th17 cell differentiation. Takahashi and collaborators have shown that at physiological doses (1nM), RA promotes Th17 cell differentiation in vitro [76]. In addition, the group of Belkaid demonstrated that $\operatorname{Rar} \alpha^{-/-} \mathrm{T}$ cells do not differentiate into Th1 or Th17 cells when cultured in vitro under Th1 or Th17 polarizing conditions [67], supporting a role of RA in the differentiation of Th1 and Th17 cells. Consistent with this evidence, several studies have reported that VAD mice show a significant impairment in Th1 and Th17 responses in vivo [67,69,75,77].

Other groups have suggested a role for RA in the induction of Th17 and Th1 responses during inflammation. It has been demonstrated that the addition of LE540, a RAR inhibitor, abrogates the in vitro Th17 cell differentiation induced by lamina propria DCs stimulated with flagellin [74]. In agreement, Rampal and collaborators have shown that retinoic-acid primed DCs can induce Th1 and Th17 cell differentiation in vitro [73]. Moreover, by studying the effects of IL-15 overproduction observed in celiac patients, DePaolo and collaborators found that RA synergizes with IL-15 to enhance IL-23 and IL-12 production by DCs, inducing Th1 cell polarization. Additionally, in the presence of IL-12 and IL-23, RA promotes Th1 and Th17 cell differentiation and inhibits Treg differentiation [78]. Furthermore, it has been demonstrated that RAR $\alpha$ deficient naive T cells fails to acquire Th1 and Th17 phenotype in a model of transplantation [37] and that RAR $\alpha$ deficient naive $T$ cells fail to differentiate into Th1 cells in a model of intestinal inflammation [70]. Taken together, these observations have led to a model where RA may have a dual effect, favoring Treg-induced suppression of Th1 and Th17 responses in the steady state while inducing Th1 and Th17 cell mediated immunity during inflammation [22].

Additional effects of RA on other cells, such as the intestinal epithelium, may be important for the regulation of Th17 cells. It has been demonstrated that VAD mice present severe alterations in the growth and function of intestinal epithelial cells, including goblet cells, which enhances mucin production. This dysfunction alters the gut microbiota, resulting in the reduction in Th17 cell numbers in the small intestine [69].

\subsection{Th2 Cell Differentiation}

In the early 1990s, the group of Hayes demonstrated for the first time that VAD mice present an imbalance in Th1 and Th2 responses [79-81]. Using a parasite that induces Th2 responses in mice, they found that hypovitaminosis A contributes to IFN- $\gamma$ overproduction, while dietary RA down-regulates Th1 responses and up-regulates Th2 responses in vivo [79]. In parallel, the group of Stephensen reached a similar conclusion when they reported that VAD impairs the salivary IgA response (associated with IL-4 production and Th2 responses) and at the same time enhances IgG2a serum levels (which is associated with IFN- $\gamma$ production and Th1 responses) [82]. Moreover, a number of clinical studies on diet supplementation with vitamin A described a modest increase in the severity of respiratory infections in children suffering from pneumonia [83], suggesting that vitamin A may participate in the induction of Th2 responses while abrogating Th1 responses. In following studies, it was reported that high levels of dietary vitamin A enhances IgA and IL-10 production [84,85], while decreasing Th1 cell differentiation in mice [86], confirming that vitamin A promotes Th2 and inhibits Th1 responses in vivo.

To study the mechanisms that drive the above mentioned effect of RA on Th2 cell differentiation, Stephensen and collaborators performed in vitro studies where naive $\mathrm{T}$ cells were cultured in the presence of all-trans-RA, 9-cis-RA or an RXR agonist. Using this setting, they demonstrated that only 9-cis-RA and the RXR agonist were able to induce IL-4 production by T cells, demonstrating that Th2 differentiation occurs via stimulation of the RXR pathway [87]. In additional in vitro studies, Iwata and collaborators demonstrated that both all-trans-RA and 9-cis-RA enhances Th2 responses and that RAR but not RXR antagonists abrogates RA induction of Th2 responses [88].

The overwhelming evidence demonstrating an effect of vitamin A on Th2 cell differentiation (and thus, indirectly on antibody production) has led to the supplementation of vaccines with vitamin A 
with the aim to increase their efficacy. Despite this, results from human immunization programs have not shown a significant effect on vaccine efficacy upon vitamin A supplementation of vaccines [4].

Aside from its effect on the Th2 adaptive immune response, recent evidence supports a role of vitamin A on the regulation of innate immune responses. The Belkaid group has shown that in contrast to the common belief that VAD is associated with global immunosuppression, the immune system is able to adapt and induce a type 2 response mediated by innate lymphoid cells (ILCs). In this study, they show that although Th2 and other T helper responses are abrogated in VAD mice, type 2 innate lymphoid cells (ILC2) are expanded, providing resistance to nematode infection in mice. Type 2 responses elicited by ILC2 cells are particularly essential for eradicating worm and parasite infections, which are prevalent in regions associated with high levels of malnutrition [77].

\subsection{T Cell Activation}

Although previous evidence has shown that RA is mainly produced by cells from the gut $[27,35,36]$, some reports have shown that RA may also be produced at other sites during an ongoing immune response $[36,37,89,90]$. Using RA signaling reporter mice (RARE-luciferase reporter mice), Pino-Lagos and collaborators showed that RA signaling occurs constitutively in areas of the small and large intestine. Importantly, the intradermal administration of activating stimuli such as LPS elicited local and transient RA signaling in the site of inflammation [37]. This finding supports a role for RA in $\mathrm{T}$ cell activation during an inflammatory immune response. Similarly, Hall and collaborators have demonstrated that RA-RAR $\alpha$ signaling is required for early T cell activation as RAR $\alpha$-deficient T cells proliferate less efficiently than their wild-type counterparts upon polyclonal activation. They further demonstrated that RAR $\alpha$ mediates events following T cell receptor activation since RAR $\alpha$-deficient T cells present decreased levels of PLC $\gamma$ and ERK phosphorylation, $\mathrm{Ca}^{2+}$ mobilization and mTOR/AKT activation upon $\mathrm{T}$ cell receptor stimulation [67]. These results strongly argue in favor of RA as an essential metabolite in the development of an appropriate immune response.

\section{Role of Retinoic Acid in Thymus and Lymphoid Organogenesis}

Thymocytes differentiate into mature $\mathrm{T}$ cells in the thymus, where they generate and express a unique $\mathrm{T}$ cell receptor. $\mathrm{T}$ cells expressing a potentially autoreactive $\mathrm{T}$ cell receptor are eliminated by apoptosis in a phenomenon known as negative selection [91]. Since the initial report of Wolbach in the early 20th century demonstrating that VAD is associated with thymic atrophy [92], several potential functions for RA in thymocyte development have been proposed. Kiss and collaborators have shown that RALDH1 is expressed by cortical and medullary thymic epithelial cells, and accordingly, all-trans-RA was detected in the murine postnatal thymus [93]. Iwata and collaborators have shown that RA inhibits TCR-mediated activation-induced thymocyte cell death in vitro, suggesting that this metabolite might affect $\mathrm{T}$ cell differentiation and negative selection in the thymus [94]. Following this report, a study using fetal thymic organ cultures showed that RA increases the proportion of mature $\mathrm{CD}^{+} \mathrm{T}$ cells that contain autoreactive $\mathrm{T}$ cells [95]. Using RAR $\alpha$-selective agonists, it was demonstrated that RAR $\alpha$ signaling is involved in the prevention of activation-induced cell death in thymocytes [96]. On the other hand, the same group reported that RA can induce thymocyte apoptosis when these cells are not activated, and this effect is mediated through RAR $\gamma$ signaling [97]. Moreover, the treatment of mice with a RAR $\gamma$ agonist induces rapid thymic involution [97]. These observations raise the possibility that RA may have an effect on negative selection in the thymus thus shaping the $\mathrm{T}$ cell repertoire in adults.

Lymphoid tissue inducer cells (LTi) constitute a subset within ILCs closely related to type 3 ILCs (ILC3s). LTi cells are essential for lymphoid organogenesis during embryogenesis, and they are also considered important regulators of lymphoid tissue architecture after birth [98-100]. Similar to Th17 cells, LTi cells are controlled by the ROR $\gamma$ t transcription factor, and thus, it has been reported that ROR $\gamma \mathrm{t}$-deficient mice do not have LTi cells and have important alterations in secondary lymph node development [101]. Recent evidence has noted a relevant role of maternal vitamin A intake in the immune fitness of the offspring. Van de Pavert recently reported a cross-talk between the developing 
neuronal system and hematopoietic stromal cells since the initiation of lymph node development is controlled by the RA-mediated expression of CXCL13 by adjacent neurons, promoting the migration of LTi cells [102]. In a following report, the same group demonstrated that local LTi cell differentiation is controlled by maternal vitamin A intake and fetal RA signaling. In this latter study, the authors demonstrate that maternal retinoids control LTi differentiation within the developing lymph nodes. Moreover, impaired RA signaling results in reduced fetal inguinal and brachial lymph node size and a reduced numbers of Peyer's patches [102]. This report reached the significant conclusion that the efficiency of adaptive immune responses against infections may be somehow pre-established during embryogenesis through vitamin A ingestion and the nutritional status of the mother.

Recently, Zhang et al. established that the gut microbiota, in particular gut fungi, is required for secondary lymphoid organ development through the induction of the migration of CD103 ${ }^{+}$DCs into the gut from the periphery. These $\mathrm{CD}_{103^{+}} \mathrm{DC}$ produce RA and signal to initiate an increase in lymph node cellularity and volume. Interestingly, they report that VAD in 5 week-old mice severely disrupts the peripheral lymph node architecture, establishing not only that gut-associated lymph nodes may be regulated by vitamin $\mathrm{A}$, as shown by van de Pavert, but also that vitamin $\mathrm{A}$ may be involved in the postnatal regulation of peripheral lymph node structure [103].

\section{Concluding Remarks}

An initial association between vitamin A supplementation and reduced childhood mortality due to measles and diarrhea led to the assumption that vitamin A was crucial in the fitness of the immune system. This finding sparked curiosity about the mechanisms through which vitamin A could modulate the immune response. Today, it is recognized that vitamin A, through its metabolite retinoic acid, is able to induce gut homing receptors on $\mathrm{T}$ and $\mathrm{B}$ cells, allowing the trafficking of these cells to the intestine (and probably also to the inflamed tissues) to perform their effector functions and maintain an appropriate gastrointestinal balance between immunity and tolerance. Moreover, exposure to vitamin $\mathrm{A}$ in the womb is an important determinant for the development of secondary lymphoid organs during embryogenesis and after birth through induction of lymphoid tissue-inducer cells. In addition, vitamin $\mathrm{A}$ has shown to be essential for $\mathrm{T}$ cell activation and differentiation into different T helper subsets, such as Th1, Th2 and Th17 cells. On the other hand, in vitro studies have shown that RA is able to induce regulatory T cells, however the role of vitamin A in promoting oral tolerance has not yet been fully established. A far more complex picture has emerged for the role of retinoic acid in gut immunity since there is contradictory evidence for several of aspects of $\mathrm{T}$ cell differentiation. Such discrepancies could be explained by the fact that RA can mediate different effects depending on the dose used in different experimental settings and the context in which an immune response is occurring. Accordingly, it has been proposed that RA may have a dual effect, modulating regulatory $\mathrm{T}$ cell differentiation in the steady state while promoting $\mathrm{T}$ cell activation and Th1 and Th17 cell responses during an ongoing immune response. In addition, results in VAD mice should be interpreted with caution; taking into consideration that VAD mice present important alterations in intestinal epithelial cells, which affects the resident microbiota. The gut microbiota has an important effect on the differentiation of $T$ helper subsets and Tregs in the gut. Therefore, the effects observed in VAD mice could be the consequence of an altered gut microbiota rather than a direct effect of RA on T cells. Although the development of better models and experimental techniques has allowed significant progress in the discovery of the mechanisms through which vitamin A broadly impacts the immune response, further studies are needed to fully unravel the role of vitamin A in T cell-mediated immunity.

Acknowledgments: This work was supported by Fondo Nacional de Desarrollo Cientifico y Tecnologico (FONDECYT) 1140431 and by Programa de Financiamiento Basal para Centros Cientificos y Tecnologicos de Excelencia PFB-16.

Author Contributions: Daniela Sauma, Mario Rosemblatt and Maria Rosa Bono conceived and designed the review. Gabriela Tejon, Felipe Flores-Santibañez and Dominique Fernandez wrote the review. Daniela Sauma, Mario Rosemblatt and Maria Rosa Bono revised the review. All authors discussed and approved the final version.

Conflicts of Interest: The authors declare no conflict of interest. 


\section{Appendix}

Table 1. Effects of RA signaling on $\mathrm{CD}^{+} \mathrm{T}$ cell differentiation in vitro.

\begin{tabular}{|c|c|c|c|}
\hline T Cell Subset & RA Effect & Experimental Setting & Model Organism [Refs] \\
\hline Treg & $\begin{array}{l}\text { Induces Treg } \\
\text { differentiation }\end{array}$ & $\begin{array}{l}\text { Cultures in the presence of RA }(0.05 \mathrm{nM}-10 \mu \mathrm{M}), \mathrm{RAR} \text { agonist } \\
\text { (AM580) or antagonists (Ro41-5253, LE540, LE135) }\end{array}$ & $\begin{array}{l}\text { Mice }[35,45-50,58,61,72] \\
\text { Human }[47,52,54]\end{array}$ \\
\hline Treg & $\begin{array}{l}\text { Enhances Treg } \\
\text { stability and } \\
\text { function }\end{array}$ & $\begin{array}{l}\text { Adoptive transfer of Treg generated in the presence of RA in mice } \\
\text { models of inflammation (immunization, transplant, intestinal } \\
\text { inflammation, GvHD) }\end{array}$ & $\begin{array}{l}\text { Mice }[49,50,58] \\
\text { Human }[52,54]\end{array}$ \\
\hline Th17 & $\begin{array}{l}\text { Induces Th17 } \\
\text { differentiation }\end{array}$ & $\begin{array}{l}\text { Cultures in the presence of physiological doses of RA }(1 \mathrm{nM}) \text { or } \\
\text { RAR antagonist (LE540). Cultures of RAR } \alpha^{-/-} \text {CD } 4^{+} \mathrm{T} \text { cells }\end{array}$ & Mice $[67,74,76]$ \\
\hline Th17 & $\begin{array}{l}\text { Reduces Th17 } \\
\text { differentiation }\end{array}$ & $\begin{array}{l}\text { Cultures in the presence of pharmacological doses of RA ( } \geqslant 10 \mathrm{nM}) \text {, } \\
\text { RAR agonist (TTNBP) or antagonist (LE135) }\end{array}$ & $\begin{array}{l}\text { Mice }[46,47,61,64,69,72,74-76 \\
\text { Human }[73]\end{array}$ \\
\hline Th1 & $\begin{array}{l}\text { Induces Th1 } \\
\text { differentiation }\end{array}$ & Cultures of RAR deficient $\mathrm{CD} 4^{+} \mathrm{T}$ cells & Mice $[67,70]$ \\
\hline Th1 & $\begin{array}{l}\text { Enhances Th1 } \\
\text { stability }\end{array}$ & Ablation of RA signaling in Th1 committed cells & Mice [70] \\
\hline Th1 & $\begin{array}{l}\text { Reduces Th1 } \\
\text { differentiation }\end{array}$ & $\begin{array}{l}\text { Cultures in the presence of pharmacological doses of RA ( } \geqslant 10 \mathrm{nM}) \text {, } \\
\text { RXR agonists (HX600, TZ335, PA024), RAR agonists (Am80, Tp80), } \\
\text { RXR antagonist (PA452) or RAR antagonists (LE135, LE540) }\end{array}$ & $\begin{array}{l}\text { Mice }[72,74,85,87] \\
\text { Human }[73]\end{array}$ \\
\hline Th2 & $\begin{array}{l}\text { Induces Th2 } \\
\text { differentiation }\end{array}$ & $\begin{array}{l}\text { Cultures in the presence of 9-cis RA }(10 \mathrm{nM}-1 \mu \mathrm{M}), \mathrm{RXR} \text { agonists } \\
\text { (AGN194204, HX600, TZ335, PA024), RAR agonists (Am80, Tp80), } \\
\text { RXR antagonist (PA452) or RAR antagonists (LE135, LE540) }\end{array}$ & Mice $[85,87,88]$ \\
\hline Th2 & $\begin{array}{l}\text { Reduces Th2 } \\
\text { differentiation }\end{array}$ & Cultures in the presence of pharmacological doses of $\mathrm{RA}(\geqslant 100 \mathrm{nM})$ & Mice [72] \\
\hline
\end{tabular}

Table 2. Effects of RA signaling on $\mathrm{CD}^{+} \mathrm{T}$ cell differentiation in vivo.

\begin{tabular}{|c|c|c|}
\hline T Cell Subset & RA Effect & Experimental Setting [Refs] \\
\hline Treg & $\begin{array}{l}\text { Induces Treg } \\
\text { differentiation }\end{array}$ & $\begin{array}{l}\text { In vivo administration RAR antagonist (LE540) in in L. monocytogenes infected mice [64] } \\
\text { VAD mice after induction of experimental autoimmune uveitis [65] } \\
\text { In vivo administration of RA in mice model of diabetes [66] } \\
\text { VAD mice after oral tolerance induction [67] }\end{array}$ \\
\hline Treg & $\begin{array}{l}\text { No effect on } \\
\text { frequencies or } \\
\text { numbers of } \\
\text { endogenous Treg }\end{array}$ & $\begin{array}{l}\text { Frequencies and/or absolute numbers of endogenous Treg in VAD mice }[67,69] \text { and RAR } \alpha^{-/-} \\
\text {mice [67] }\end{array}$ \\
\hline Th17 & $\begin{array}{l}\text { Reduces Th17 } \\
\text { differentiation }\end{array}$ & $\begin{array}{l}\text { Frequencies of Th17 cells in small intestine lamina propria after oral administration of RA in } \\
\text { L. monocytogenes infected mice [64] } \\
\text { Endogenous response to L. monocytogenes in CD4 conditional RAR } \alpha \text {-deficient mice [70] } \\
\text { CD4 conditional RAR } \alpha \text {-deficient mice in spleen at steady state [70] } \\
\text { In vivo differentiation of RAR } \alpha \text { deficient CD } 4^{+} \text {T cells in mice model of intestinal inflammation [70] } \\
\text { Frequencies of Th17 cells in spleen after intraperitoneal administration of RA in experimental } \\
\text { autoimmune encephalomyelitis mice [61] }\end{array}$ \\
\hline Th1 & $\begin{array}{l}\text { Induces Th1 } \\
\text { differentiation }\end{array}$ & $\begin{array}{l}\text { CD4 conditional RAR } \alpha \text {-deficient mice in spleen at steady state [70] } \\
\text { Endogenous response to L. monocytogenes in CD4 conditional RAR } \alpha \text {-deficient mice [70] } \\
\text { In vivo differentiation of RAR } \alpha \text { deficient CD4 } 4^{+} \mathrm{T} \text { cells in mice model of intestinal inflammation [70] } \\
\text { In vivo differentiation of RAR } \alpha \text { deficient CD } 4^{+} \mathrm{T} \text { cells in mice model of transplantation [37] } \\
\text { In vivo differentiation of CD4 }{ }^{+} \mathrm{T} \text { cells after immunization with cognate antigen in VAD mice [86] }\end{array}$ \\
\hline Th1 & $\begin{array}{l}\text { Impairs Th1 } \\
\text { responses }\end{array}$ & $\begin{array}{l}\text { Influenza-specific IgG and IFN- } \gamma \text { production after intranasal inoculation with influenza virus in VAD } \\
\text { mice [82] or mice fed with a vitamin A-rich diet [84] } \\
\text { Antigen-specific IFN- } \gamma \text { production in mesenteric lymph node and spleen cells after infection with } \\
\text { T. spiralis in VAD mice }[79,81]\end{array}$ \\
\hline Th2 & $\begin{array}{l}\text { Induces Th2 } \\
\text { differentiation }\end{array}$ & $\begin{array}{l}\text { Influenza-specific IgA and IL-10 production after intranasal inoculation with influenza virus in VAD } \\
\text { mice [82] or mice fed with a vitamin A-rich diet [84] } \\
\text { Antigen-specific IL-4, IL-5 production in mesenteric lymph node cells after infection with T. spiralis in } \\
\text { VAD mice [79,81] } \\
\text { In vivo differentiation of } C D 4^{+} \text {T cells after immunization with cognate antigen in VAD mice [86] }\end{array}$ \\
\hline
\end{tabular}




\section{References}

1. Sommer, A. Vitamin A deficiency and clinical disease: An historical overview. J. Nutr. 2008, 138, $1835-1839$. [PubMed]

2. Green, H.N.; Mellanby, E. Vitamin A as an anti-infective agent. Br. Med. J. 1928, 2, 691-696. [CrossRef] [PubMed]

3. Glasziou, P.P.; Mackerras, D.E. Vitamin A supplementation in infectious diseases: A meta-analysis. BMJ 1993, 306, 366-370. [CrossRef] [PubMed]

4. WHO IRIS. Available online: http:/ /apps.who.int/iris/handle/10665/61514 (accessed on 2 June 2016).

5. WHO. Available online: http://www.who.int/vmnis/database/vitamina/x/en/ (accessed on 2 June 2016).

6. Schaible, U.E.; Kaufmann, S.H. Malnutrition and infection: Complex mechanisms and global impacts. PLoS Med. 2007, 4. [CrossRef] [PubMed]

7. Blomhoff, R.; Blomhoff, H.K. Overview of retinoid metabolism and function. J. Neurobiol. 2006, 66, 606-630. [CrossRef] [PubMed]

8. Hall, J.A.; Grainger, J.R.; Spencer, S.P.; Belkaid, Y. The role of retinoic acid in tolerance and immunity. Immunity 2011, 35, 13-22. [CrossRef] [PubMed]

9. Burns, M.E.; Baylor, D.A. Activation, deactivation, and adaptation in vertebrate photoreceptor cells. Annu. Rev. Neurosci. 2001, 24, 779-805. [CrossRef] [PubMed]

10. Newcomer, M.E.; Ong, D.E. Plasma retinol binding protein: Structure and function of the prototypic lipocalin. Biochim. Biophys. Acta. 2000, 1482, 57-64. [CrossRef]

11. Napoli, J.L. Retinoic acid: Its biosynthesis and metabolism. Prog. Nucleic Acid Res. Mol. Biol. 1999, 63, 139-188. [PubMed]

12. Duester, G. Families of retinoid dehydrogenases regulating vitamin A function: Production of visual pigment and retinoic acid. Eur. J. Biochem. 2000, 267, 4315-4324. [CrossRef] [PubMed]

13. Sandell, L.L.; Sanderson, B.W.; Moiseyev, G.; Johnson, T.; Mushegian, A.; Young, K.; Rey, J.P.; Ma, J.X.; Staehling-Hampton, K.; Trainor, P.A. RDH10 is essential for synthesis of embryonic retinoic acid and is required for limb, craniofacial, and organ development. Genes Dev. 2007, 21, 1113-1124. [CrossRef] [PubMed]

14. Guo, Y.; Brown, C.; Ortiz, C.; Noelle, R.J. Leukocyte homing, fate, and function are controlled by retinoic acid. Physiol. Rev. 2015, 95, 125-148. [CrossRef] [PubMed]

15. Dolle, P.; Ruberte, E.; Kastner, P.; Petkovich, M.; Stoner, C.M.; Gudas, L.J.; Chambon, P. Differential expression of genes encoding alpha, beta and gamma retinoic acid receptors and crabp in the developing limbs of the mouse. Nature 1989, 342, 702-705. [CrossRef] [PubMed]

16. Balmer, J.E.; Blomhoff, R. Gene expression regulation by retinoic acid. J. Lipid Res. 2002, 43, 1773-1808. [CrossRef] [PubMed]

17. Durand, B.; Saunders, M.; Leroy, P.; Leid, M.; Chambon, P. All-trans and 9-cis retinoic acid induction of CRABPII transcription is mediated by RAR-RXR heterodimers bound to DR1 and DR2 repeated motifs. Cell 1992, 71, 73-85. [CrossRef]

18. Heyman, R.A.; Mangelsdorf, D.J.; Dyck, J.A.; Stein, R.B.; Eichele, G.; Evans, R.M.; Thaller, C. 9-cis retinoic acid is a high affinity ligand for the retinoid $X$ receptor. Cell 1992, 68, 397-406. [CrossRef]

19. Kurokawa, R.; DiRenzo, J.; Boehm, M.; Sugarman, J.; Gloss, B.; Rosenfeld, M.G.; Heyman, R.A.; Glass, C.K. Regulation of retinoid signalling by receptor polarity and allosteric control of ligand binding. Nature 1994, 371, 528-531. [CrossRef] [PubMed]

20. Kurokawa, R.; Soderstrom, M.; Horlein, A.; Halachmi, S.; Brown, M.; Rosenfeld, M.G.; Glass, C.K. Polarity-specific activities of retinoic acid receptors determined by a co-repressor. Nature 1995, 377, 451-454. [CrossRef] [PubMed]

21. Westin, S.; Kurokawa, R.; Nolte, R.T.; Wisely, G.B.; McInerney, E.M.; Rose, D.W.; Milburn, M.V.; Rosenfeld, M.G.; Glass, C.K. Interactions controlling the assembly of nuclear-receptor heterodimers and co-activators. Nature 1998, 395, 199-202. [PubMed]

22. Raverdeau, M.; Mills, K.H. Modulation of T cell and innate immune responses by retinoic acid. J. Immunol. 2014, 192, 2953-2958. [CrossRef] [PubMed]

23. Mora, J.R.; von Andrian, U.H. T-cell homing specificity and plasticity: New concepts and future challenges. Trends Immunol. 2006, 27, 235-243. [CrossRef] [PubMed] 
24. Bono, M.R.; Elgueta, R.; Sauma, D.; Pino, K.; Osorio, F.; Michea, P.; Fierro, A.; Rosemblatt, M. The essential role of chemokines in the selective regulation of lymphocyte homing. Cytokine Growth Factor Rev. 2007, 18, 33-43. [CrossRef] [PubMed]

25. Hosoe, N.; Miura, S.; Watanabe, C.; Tsuzuki, Y.; Hokari, R.; Oyama, T.; Fujiyama, Y.; Nagata, H.; Ishii, H. Demonstration of functional role of TECK/CCL25 in T lymphocyte-endothelium interaction in inflamed and uninflamed intestinal mucosa. Am. J. Physiol. Gastrointest. Liver Physiol. 2004, 286, G458-G466. [CrossRef] [PubMed]

26. Mora, J.R.; Bono, M.R.; Manjunath, N.; Weninger, W.; Cavanagh, L.L.; Rosemblatt, M.; von Andrian, U.H. Selective imprinting of gut-homing T cells by peyer's patch dendritic cells. Nature 2003, 424, 88-93. [CrossRef] [PubMed]

27. Iwata, M.; Hirakiyama, A.; Eshima, Y.; Kagechika, H.; Kato, C.; Song, S.Y. Retinoic acid imprints gut-homing specificity on T cells. Immunity 2004, 21, 527-538. [CrossRef] [PubMed]

28. Svensson, M.; Johansson-Lindbom, B.; Zapata, F.; Jaensson, E.; Austenaa, L.M.; Blomhoff, R.; Agace, W.W. Retinoic acid receptor signaling levels and antigen dose regulate gut homing receptor expression on CD8 ${ }^{+}$ T cells. Mucosal. Immunol. 2008, 1, 38-48. [CrossRef] [PubMed]

29. Mora, J.R.; Iwata, M.; Eksteen, B.; Song, S.Y.; Junt, T.; Senman, B.; Otipoby, K.L.; Yokota, A.; Takeuchi, H.; Ricciardi-Castagnoli, P.; et al. Generation of gut-homing IgA-secreting B cells by intestinal dendritic cells. Science 2006, 314, 1157-1160. [CrossRef] [PubMed]

30. Mora, J.R.; von Andrian, U.H. Role of retinoic acid in the imprinting of gut-homing IgA-secreting cells. Semin. Immunol. 2009, 21, 28-35. [CrossRef] [PubMed]

31. DeNucci, C.C.; Pagan, A.J.; Mitchell, J.S.; Shimizu, Y. Control of $\alpha 4 \beta 7$ integrin expression and CD4 T cell homing by the $\beta 1$ integrin subunit. J. Immunol. 2010, 184, 2458-2467. [CrossRef] [PubMed]

32. Kang, S.G.; Park, J.; Cho, J.Y.; Ulrich, B.; Kim, C.H. Complementary roles of retinoic acid and TGF- $\beta 1$ in coordinated expression of mucosal integrins by T cells. Mucosal. Immunol. 2011, 4, 66-82. [CrossRef] [PubMed]

33. Ohoka, Y.; Yokota, A.; Takeuchi, H.; Maeda, N.; Iwata, M. Retinoic acid-induced CCR9 expression requires transient TCR stimulation and cooperativity between NFATc2 and the retinoic acid receptor/retinoid $\mathrm{X}$ receptor complex. J. Immunol. 2011, 186, 733-744. [CrossRef] [PubMed]

34. Bakdash, G.; Vogelpoel, L.T.; van Capel, T.M.; Kapsenberg, M.L.; de Jong, E.C. Retinoic acid primes human dendritic cells to induce gut-homing, IL-10-producing regulatory T cells. Mucosal. Immunol. 2015, 8, 265-278. [CrossRef] [PubMed]

35. Coombes, J.L.; Siddiqui, K.R.; Arancibia-Carcamo, C.V.; Hall, J.; Sun, C.M.; Belkaid, Y.; Powrie, F. A functionally specialized population of mucosal $\mathrm{CD}_{103^{+}} \mathrm{DC}$ induces Foxp ${ }^{+}$regulatory $\mathrm{T}$ cells via a TGF- $\beta$-and retinoic acid-dependent mechanism. J. Exp. Med. 2007, 204, 1757-1764. [CrossRef] [PubMed]

36. Hammerschmidt, S.I.; Ahrendt, M.; Bode, U.; Wahl, B.; Kremmer, E.; Forster, R.; Pabst, O. Stromal mesenteric lymph node cells are essential for the generation of gut-homing T cells in vivo. J. Exp. Med. 2008, 205, 2483-2490. [CrossRef] [PubMed]

37. Pino-Lagos, K.; Guo, Y.; Brown, C.; Alexander, M.P.; Elgueta, R.; Bennett, K.A.; de Vries, V.; Nowak, E.; Blomhoff, R.; Sockanathan, S.; et al. A retinoic acid-dependent checkpoint in the development of CD4 ${ }^{+}$ T cell-mediated immunity. J. Exp. Med. 2011, 208, 1767-1775. [CrossRef] [PubMed]

38. Pabst, O.; Mowat, A.M. Oral tolerance to food protein. Mucosal. Immunol. 2012, 5, 232-239. [CrossRef] [PubMed]

39. Wing, K.; Sakaguchi, S. Regulatory T cells exert checks and balances on self tolerance and autoimmunity. Nat. Immunol. 2010, 11, 7-13. [CrossRef] [PubMed]

40. Josefowicz, S.Z.; Rudensky, A. Control of regulatory T cell lineage commitment and maintenance. Immunity 2009, 30, 616-625. [CrossRef] [PubMed]

41. Karim, M.; Kingsley, C.I.; Bushell, A.R.; Sawitzki, B.S.; Wood, K.J. Alloantigen-induced CD25 $5^{+}$CD4 ${ }^{+}$ regulatory $\mathrm{T}$ cells can develop in vivo from $\mathrm{CD} 25^{-} \mathrm{CD} 4^{+}$precursors in a thymus-independent process. J. Immunol. 2004, 172, 923-928. [CrossRef] [PubMed]

42. Vukmanovic-Stejic, M.; Zhang, Y.; Cook, J.E.; Fletcher, J.M.; McQuaid, A.; Masters, J.E.; Rustin, M.H.; Taams, L.S.; Beverley, P.C.; Macallan, D.C.; et al. Human CD4 ${ }^{+}$CD25 ${ }^{\text {hi }}$ Foxp3 ${ }^{+}$regulatory T cells are derived by rapid turnover of memory populations in vivo. J. Clin. Investig. 2006, 116, 2423-2433. [CrossRef] [PubMed] 
43. Yamagiwa, S.; Gray, J.D.; Hashimoto, S.; Horwitz, D.A. A role for TGF- $\beta$ in the generation and expansion of $\mathrm{CD}^{+} \mathrm{CD} 25^{+}$regulatory $\mathrm{T}$ cells from human peripheral blood. J. Immunol. 2001, 166, 7282-7289. [CrossRef] [PubMed]

44. Hori, S.; Nomura, T.; Sakaguchi, S. Control of regulatory T cell development by the transcription factor Foxp3. Science 2003, 299, 1057-1061. [CrossRef] [PubMed]

45. Sun, C.M.; Hall, J.A.; Blank, R.B.; Bouladoux, N.; Oukka, M.; Mora, J.R.; Belkaid, Y. Small intestine lamina propria dendritic cells promote de novo generation of Foxp3 T reg cells via retinoic acid. J. Exp. Med. 2007, 204, 1775-1785. [CrossRef] [PubMed]

46. Schambach, F.; Schupp, M.; Lazar, M.A.; Reiner, S.L. Activation of retinoic acid receptor- $\alpha$ favours regulatory $\mathrm{T}$ cell induction at the expense of IL-17-secreting T helper cell differentiation. Eur. J. Immunol. 2007, 37, 2396-2399. [CrossRef] [PubMed]

47. Kang, S.G.; Lim, H.W.; Andrisani, O.M.; Broxmeyer, H.E.; Kim, C.H. Vitamin A metabolites induce gut-homing Foxp3 $3^{+}$regulatory T cells. J. Immunol. 2007, 179, 3724-3733. [CrossRef] [PubMed]

48. Mucida, D.; Pino-Lagos, K.; Kim, G.; Nowak, E.; Benson, M.J.; Kronenberg, M.; Noelle, R.J.; Cheroutre, H. Retinoic acid can directly promote TGF- $\beta$-mediated Foxp3+ Treg cell conversion of naive T cells. Immunity 2009, 30, 471-473. [CrossRef] [PubMed]

49. Moore, C.; Tejon, G.; Fuentes, C.; Hidalgo, Y.; Bono, M.R.; Maldonado, P.; Fernandez, R.; Wood, K.J.; Fierro, J.A.; Rosemblatt, M.; et al. Alloreactive regulatory T cells generated with retinoic acid prevent skin allograft rejection. Eur. J. Immunol. 2015, 45, 452-463. [CrossRef] [PubMed]

50. Benson, M.J.; Pino-Lagos, K.; Rosemblatt, M.; Noelle, R.J. All-trans retinoic acid mediates enhanced T reg cell growth, differentiation, and gut homing in the face of high levels of co-stimulation. J. Exp. Med. 2007, 204, 1765-1774. [CrossRef] [PubMed]

51. Golovina, T.N.; Mikheeva, T.; Brusko, T.M.; Blazar, B.R.; Bluestone, J.A.; Riley, J.L. Retinoic acid and rapamycin differentially affect and synergistically promote the ex vivo expansion of natural human T regulatory cells. PLoS ONE 2011, 6. [CrossRef] [PubMed]

52. Lu, L.; Zhou, X.; Wang, J.; Zheng, S.G.; Horwitz, D.A. Characterization of protective human CD4 ${ }^{+} \mathrm{CD} 25^{+}$ Foxp $3^{+}$regulatory T cells generated with IL-2, TGF- $\beta$ and retinoic acid. PLoS ONE 2010, 5. [CrossRef] [PubMed]

53. Scotta, C.; Esposito, M.; Fazekasova, H.; Fanelli, G.; Edozie, F.C.; Ali, N.; Xiao, F.; Peakman, M.; Afzali, B.; Sagoo, P.; et al. Differential effects of rapamycin and retinoic acid on expansion, stability and suppressive qualities of human $\mathrm{CD}^{+} \mathrm{CD}^{+} 5^{+}$Foxp3 $^{+}$T regulatory cell subpopulations. Haematologica 2013, 98, 1291-1299. [CrossRef] [PubMed]

54. Wang, J.; Huizinga, T.W.; Toes, R.E. De novo generation and enhanced suppression of human CD4 ${ }^{+}$CD25 $5^{+}$ regulatory T cells by retinoic acid. J. Immunol. 2009, 183, 4119-4126. [CrossRef] [PubMed]

55. Nolting, J.; Daniel, C.; Reuter, S.; Stuelten, C.; Li, P.; Sucov, H.; Kim, B.G.; Letterio, J.J.; Kretschmer, K.; Kim, H.J.; et al. Retinoic acid can enhance conversion of naive into regulatory $\mathrm{T}$ cells independently of secreted cytokines. J. Exp. Med. 2009, 206, 2131-2139. [CrossRef] [PubMed]

56. Hill, J.A.; Hall, J.A.; Sun, C.M.; Cai, Q.; Ghyselinck, N.; Chambon, P.; Belkaid, Y.; Mathis, D.; Benoist, C. Retinoic acid enhances Foxp3 induction indirectly by relieving inhibition from $\mathrm{CD} 4{ }^{+} \mathrm{CD} 44 \mathrm{hi}$ cells. Immunity 2008, 29, 758-770. [CrossRef] [PubMed]

57. Takeuchi, H.; Yokota-Nakatsuma, A.; Ohoka, Y.; Kagechika, H.; Kato, C.; Song, S.Y.; Iwata, M. Retinoid $\mathrm{X}$ receptor agonists modulate Foxp $3^{+}$regulatory $\mathrm{T}$ cell and Th17 cell differentiation with differential dependence on retinoic acid receptor activation. J. Immunol. 2013, 191, 3725-3733. [CrossRef] [PubMed]

58. Tejon, G.; Manriquez, V.; de Calisto, J.; Flores-Santibanez, F.; Hidalgo, Y.; Crisostomo, N.; Fernandez, D.; Sauma, D.; Mora, J.R.; Bono, M.R.; et al. Vitamin A impairs the reprogramming of Tregs into IL-17-producing cells during intestinal inflammation. Biomed. Res. Int. 2015, 2015, 137893. [CrossRef] [PubMed]

59. Zhou, X.; Kong, N.; Wang, J.; Fan, H.; Zou, H.; Horwitz, D.; Brand, D.; Liu, Z.; Zheng, S.G. Cutting edge: All-trans retinoic acid sustains the stability and function of natural regulatory $\mathrm{T}$ cells in an inflammatory milieu. J. Immunol. 2010, 185, 2675-2679. [CrossRef] [PubMed]

60. Mucida, D.; Park, Y.; Cheroutre, H. From the diet to the nucleus: Vitamin a and TGF- $\beta$ join efforts at the mucosal interface of the intestine. Semin. Immunol. 2009, 21, 14-21. [CrossRef] [PubMed] 
61. Xiao, S.; Jin, H.; Korn, T.; Liu, S.M.; Oukka, M.; Lim, B.; Kuchroo, V.K. Retinoic acid increases Foxp3 ${ }^{+}$ regulatory T cells and inhibits development of Th17 cells by enhancing TGF- $\beta$-driven Smad 3 signaling and inhibiting IL-6 and IL-23 receptor expression. J. Immunol. 2008, 181, 2277-2284. [CrossRef] [PubMed]

62. Moore, C.; Sauma, D.; Morales, J.; Bono, M.R.; Rosemblatt, M.; Fierro, J.A. Transforming growth factor- $\beta$ and all-trans retinoic acid generate ex vivo transgenic regulatory $\mathrm{T}$ cells with intestinal homing receptors. Transplant. Proc. 2009, 41, 2670-2672. [CrossRef] [PubMed]

63. Ruiz, P.; Maldonado, P.; Hidalgo, Y.; Sauma, D.; Rosemblatt, M.; Bono, M.R. Alloreactive regulatory T cells allow the generation of mixed chimerism and transplant tolerance. Front. Immunol. 2015, 6. [CrossRef] [PubMed]

64. Mucida, D.; Park, Y.; Kim, G.; Turovskaya, O.; Scott, I.; Kronenberg, M.; Cheroutre, H. Reciprocal Th17 and regulatory $\mathrm{T}$ cell differentiation mediated by retinoic acid. Science 2007, 317, 256-260. [CrossRef] [PubMed]

65. Kawazoe, Y.; Sugita, S.; Keino, H.; Yamada, Y.; Imai, A.; Horie, S.; Mochizuki, M. Retinoic acid from retinal pigment epithelium induces T regulatory cells. Exp. Eye Res. 2012, 94, 32-40. [CrossRef] [PubMed]

66. Van, Y.H.; Lee, W.H.; Ortiz, S.; Lee, M.H.; Qin, H.J.; Liu, C.P. All-trans retinoic acid inhibits type 1 diabetes by $\mathrm{T}$ regulatory (Treg)-dependent suppression of interferon- $\gamma$-producing T-cells without affecting Th17 cells. Diabetes 2009, 58, 146-155. [CrossRef] [PubMed]

67. Hall, J.A.; Cannons, J.L.; Grainger, J.R.; Dos Santos, L.M.; Hand, T.W.; Naik, S.; Wohlfert, E.A.; Chou, D.B.; Oldenhove, G.; Robinson, M.; et al. Essential role for retinoic acid in the promotion of $\mathrm{CD} 4^{+} \mathrm{T}$ cell effector responses via retinoic acid receptor alpha. Immunity 2011, 34, 435-447. [CrossRef] [PubMed]

68. Hadis, U.; Wahl, B.; Schulz, O.; Hardtke-Wolenski, M.; Schippers, A.; Wagner, N.; Muller, W.; Sparwasser, T.; Forster, R.; Pabst, O. Intestinal tolerance requires gut homing and expansion of Foxp3 ${ }^{+}$regulatory $\mathrm{T}$ cells in the lamina propria. Immunity 2011, 34, 237-246. [CrossRef] [PubMed]

69. Cha, H.R.; Chang, S.Y.; Chang, J.H.; Kim, J.O.; Yang, J.Y.; Kim, C.H.; Kweon, M.N. Downregulation of Th17 cells in the small intestine by disruption of gut flora in the absence of retinoic acid. J. Immunol 2010, 184, 6799-6806. [CrossRef] [PubMed]

70. Brown, C.C.; Esterhazy, D.; Sarde, A.; London, M.; Pullabhatla, V.; Osma-Garcia, I.; Al-Bader, R.; Ortiz, C.; Elgueta, R.; Arno, M.; et al. Retinoic acid is essential for Th1 cell lineage stability and prevents transition to a Th17 cell program. Immunity 2015, 42, 499-511. [CrossRef] [PubMed]

71. Zhu, J.; Yamane, H.; Paul, W.E. Differentiation of effector CD4 T cell populations. Annu. Rev. Immunol. 2010, 28, 445-489. [CrossRef] [PubMed]

72. Elias, K.M.; Laurence, A.; Davidson, T.S.; Stephens, G.; Kanno, Y.; Shevach, E.M.; O'Shea, J.J. Retinoic acid inhibits Th17 polarization and enhances FoxP3 expression through a Stat-3/Stat-5 independent signaling pathway. Blood 2008, 111, 1013-1020. [CrossRef] [PubMed]

73. Rampal, R.; Awasthi, A.; Ahuja, V. Retinoic acid-primed human dendritic cells inhibit Th9 cells and induce Th1/Th17 cell differentiation. J. Leukoc. Biol. 2016. [CrossRef] [PubMed]

74. Uematsu, S.; Fujimoto, K.; Jang, M.H.; Yang, B.G.; Jung, Y.J.; Nishiyama, M.; Sato, S.; Tsujimura, T.; Yamamoto, M.; Yokota, Y.; et al. Regulation of humoral and cellular gut immunity by lamina propria dendritic cells expressing Toll-like receptor 5. Nat. Immunol. 2008, 9, 769-776. [CrossRef] [PubMed]

75. Wang, C.; Kang, S.G.; HogenEsch, H.; Love, P.E.; Kim, C.H. Retinoic acid determines the precise tissue tropism of inflammatory Th17 cells in the intestine. J. Immunol. 2010, 184, 5519-5526. [CrossRef] [PubMed]

76. Takahashi, H.; Kanno, T.; Nakayamada, S.; Hirahara, K.; Sciume, G.; Muljo, S.A.; Kuchen, S.; Casellas, R.; Wei, L.; Kanno, Y.; et al. TGF-[beta] and retinoic acid induce the microRNA miR-10a, which targets Bcl-6 and constrains the plasticity of helper T cells. Nat. Immunol. 2012, 13, 587-595. [CrossRef] [PubMed]

77. Spencer, S.P.; Wilhelm, C.; Yang, Q.; Hall, J.A.; Bouladoux, N.; Boyd, A.; Nutman, T.B.; Urban, J.F., Jr.; Wang, J.; Ramalingam, T.R.; et al. Adaptation of innate lymphoid cells to a micronutrient deficiency promotes type 2 barrier immunity. Science 2014, 343, 432-437. [CrossRef] [PubMed]

78. DePaolo, R.W.; Abadie, V.; Tang, F.; Fehlner-Peach, H.; Hall, J.A.; Wang, W.; Marietta, E.V.; Kasarda, D.D.; Waldmann, T.A.; Murray, J.A.; et al. Co-adjuvant effects of retinoic acid and IL-15 induce inflammatory immunity to dietary antigens. Nature 2011, 471, 220-224. [CrossRef] [PubMed]

79. Cantorna, M.T.; Nashold, F.E.; Hayes, C.E. In vitamin A deficiency multiple mechanisms establish a regulatory $\mathrm{T}$ helper cell imbalance with excess Th1 and insufficient Th2 function. J. Immunol. 1994, 152, 1515-1522. [PubMed] 
80. Carman, J.A.; Hayes, C.E. Abnormal regulation of IFN-gamma secretion in vitamin A deficiency. J. Immunol. 1991, 147, 1247-1252. [PubMed]

81. Carman, J.A.; Pond, L.; Nashold, F.; Wassom, D.L.; Hayes, C.E. Immunity to trichinella spiralis infection in vitamin A-deficient mice. J. Exp. Med. 1992, 175, 111-120. [CrossRef] [PubMed]

82. Stephensen, C.B.; Moldoveanu, Z.; Gangopadhyay, N.N. Vitamin A deficiency diminishes the salivary immunoglobulin A response and enhances the serum immunoglobulin $G$ response to influenza A virus infection in BALB/c mice. J. Nutr. 1996, 126, 94-102. [PubMed]

83. Stephensen, C.B.; Franchi, L.M.; Hernandez, H.; Campos, M.; Gilman, R.H.; Alvarez, J.O. Adverse effects of high-dose vitamin A supplements in children hospitalized with pneumonia. Pediatrics 1998, 101. [CrossRef]

84. Cui, D.; Moldoveanu, Z.; Stephensen, C.B. High-level dietary vitamin A enhances T-helper type 2 cytokine production and secretory immunoglobulin A response to influenza A virus infection in BALB/c mice. J. Nutr. 2000, 130, 1132-1139. [PubMed]

85. Racke, M.K.; Burnett, D.; Pak, S.H.; Albert, P.S.; Cannella, B.; Raine, C.S.; McFarlin, D.E.; Scott, D.E. Retinoid treatment of experimental allergic encephalomyelitis. IL-4 production correlates with improved disease course. J. Immunol. 1995, 154, 450-458. [PubMed]

86. Stephensen, C.B.; Jiang, X.; Freytag, T. Vitamin A deficiency increases the in vivo development of IL-10-positive Th2 cells and decreases development of Th1 cells in mice. J. Nutr. 2004, 134, 2660-2666. [PubMed]

87. Stephensen, C.B.; Rasooly, R.; Jiang, X.; Ceddia, M.A.; Weaver, C.T.; Chandraratna, R.A.; Bucy, R.P. Vitamin A enhances in vitro Th2 development via retinoid $X$ receptor pathway. J. Immunol. 2002, 168, 4495-4503. [CrossRef] [PubMed]

88. Iwata, M.; Eshima, Y.; Kagechika, H. Retinoic acids exert direct effects on T cells to suppress Th1 development and enhance Th2 development via retinoic acid receptors. Int. Immunol. 2003, 15, 1017-1025. [CrossRef] [PubMed]

89. Guilliams, M.; Crozat, K.; Henri, S.; Tamoutounour, S.; Grenot, P.; Devilard, E.; de Bovis, B.; Alexopoulou, L.; Dalod, M.; Malissen, B. Skin-draining lymph nodes contain dermis-derived CD103- dendritic cells that constitutively produce retinoic acid and induce Foxp3 ${ }^{+}$regulatory T cells. Blood 2010, 115, 1958-1968. [CrossRef] [PubMed]

90. Molenaar, R.; Greuter, M.; van der Marel, A.P.; Roozendaal, R.; Martin, S.F.; Edele, F.; Huehn, J.; Forster, R.; O'Toole, T.; Jansen, W.; et al. Lymph node stromal cells support dendritic cell-induced gut-homing of T cells. J. Immunol. 2009, 183, 6395-6402. [CrossRef] [PubMed]

91. Blackman, M.; Kappler, J.; Marrack, P. The role of the T cell receptor in positive and negative selection of developing T cells. Science 1990, 248, 1335-1341. [CrossRef] [PubMed]

92. Wolbach, S.B.; Howe, P.R. Tissue changes following deprivation of fat-soluble A vitamin. J. Exp. Med. 1925, 42, 753-777. [CrossRef] [PubMed]

93. Kiss, I.; Ruhl, R.; Szegezdi, E.; Fritzsche, B.; Toth, B.; Pongracz, J.; Perlmann, T.; Fesus, L.; Szondy, Z. Retinoid receptor-activating ligands are produced within the mouse thymus during postnatal development. Eur. J. Immunol. 2008, 38, 147-155. [CrossRef] [PubMed]

94. Iwata, M.; Mukai, M.; Nakai, Y.; Iseki, R. Retinoic acids inhibit activation-induced apoptosis in T cell hybridomas and thymocytes. J. Immunol. 1992, 149, 3302-3308. [PubMed]

95. Yagi, J.; Uchida, T.; Kuroda, K.; Uchiyama, T. Influence of retinoic acid on the differentiation pathway of T cells in the thymus. Cell Immunol. 1997, 181, 153-162. [CrossRef] [PubMed]

96. Szondy, Z.; Reichert, U.; Bernardon, J.M.; Michel, S.; Toth, R.; Karaszi, E.; Fesus, L. Inhibition of activation-induced apoptosis of thymocytes by all-trans- and 9-cis-retinoic acid is mediated via retinoic acid receptor $\alpha$. Biochem. J. 1998, 331, 767-774. [CrossRef] [PubMed]

97. Szondy, Z.; Reichert, U.; Bernardon, J.M.; Michel, S.; Toth, R.; Ancian, P.; Ajzner, E.; Fesus, L. Induction of apoptosis by retinoids and retinoic acid receptor $\gamma$-selective compounds in mouse thymocytes through a novel apoptosis pathway. Mol. Pharmacol. 1997, 51, 972-982. [PubMed]

98. Mebius, R.E.; Rennert, P.; Weissman, I.L. Developing lymph nodes collect CD4 ${ }^{+}$CD3 ${ }^{-}$LT $\beta^{+}$cells that can differentiate to APC, NK cells, and follicular cells but not T or B cells. Immunity 1997, 7, 493-504. [CrossRef]

99. Walker, J.A.; Barlow, J.L.; McKenzie, A.N. Innate lymphoid cells—how did we miss them? Nat. Rev. Immunol. 2013, 13, 75-87. [CrossRef] [PubMed] 
100. Yoshida, H.; Honda, K.; Shinkura, R.; Adachi, S.; Nishikawa, S.; Maki, K.; Ikuta, K.; Nishikawa, S.I. IL-7 receptor $\alpha^{+} \mathrm{CD}^{-}$cells in the embryonic intestine induces the organizing center of Peyer's patches. Int. Immunol. 1999, 11, 643-655. [CrossRef] [PubMed]

101. Eberl, G.; Marmon, S.; Sunshine, M.J.; Rennert, P.D.; Choi, Y.; Littman, D.R. An essential function for the nuclear receptor ROR $\gamma \mathrm{t}$ in the generation of fetal lymphoid tissue inducer cells. Nat. Immunol. 2004, 5, 64-73. [CrossRef] [PubMed]

102. Van de Pavert, S.A.; Ferreira, M.; Domingues, R.G.; Ribeiro, H.; Molenaar, R.; Moreira-Santos, L.; Almeida, F.F.; Ibiza, S.; Barbosa, I.; Goverse, G.; et al. Maternal retinoids control type 3 innate lymphoid cells and set the offspring immunity. Nature 2014, 508, 123-127. [CrossRef] [PubMed]

103. Zhang, Z.; Li, J.; Zheng, W.; Zhao, G.; Zhang, H.; Wang, X.; Guo, Y.; Qin, C.; Shi, Y. Peripheral lymphoid volume expansion and maintenance are controlled by gut microbiota via $\mathrm{RALDH}^{+}$dendritic cells. Immunity 2016, 44, 330-342. [CrossRef] [PubMed]

(C) 2016 by the authors; licensee MDPI, Basel, Switzerland. This article is an open access article distributed under the terms and conditions of the Creative Commons Attribution (CC-BY) license (http://creativecommons.org/licenses/by/4.0/). 